\title{
Identification of rare alternative splicing events in MS/MS data reveals a significant fraction of alternative translation initiation sites
}

Integration of transcriptome data is a crucial step for the identification of rare protein variants in mass-spectrometry (MS) data with important consequences for all branches of biotechnology research. Here, we used Splooce, a database of splicing variants recently developed by us, to search MS data derived from a variety of human tumor cell lines. More than 800 new protein variants were identified whose corresponding MS spectra were specific to protein entries from Splooce. Although the types of splicing variants (exon skipping, alternative splice sites and intron retention) were found at the same frequency as in the transcriptome, we observed a large variety of modifications at the protein level induced by alternative splicing events. Surprisingly, we found that $40 \%$ of all protein modifications induced by alternative splicing led to the use of alternative translation initiation sites. Other modifications include frameshifts in the open reading frame and inclusion or deletion of peptide sequences. To make the dataset generated here available to the community in a more effective form, the Splooce portal (http://www.bioinformaticsbrazil.org/splooce) was modified to report the alternative splicing events supported by MS data. 
3 José E. Kroll ${ }^{1,2}$, Sandro J. de Souza ${ }^{2}$ and Gustavo A. de Souza ${ }^{3 *}$

4 1. Institute of Bioinformatics and Biotechnology, R. da Palestina 99 sala 109, CEP 59092-

$5 \quad 460$ Natal, Brazil

6 2. Brain Institute, UFRN, Av. Nascimento de Castro 2155, CEP 59056-450, Natal, Brazil

7 3. Dept. of Immunology and Centre for Immune Regulation, Oslo University Hospital HF

8 Rikshospitalet, University of Oslo, Oslo, Norway.

$9 *$ Correspondence should be addressed to:

10 Gustavo A. de Souza,

11 PO Box 4950 Nydalen, 0424 Oslo, Norway

12 g.a.d.souza@medisin.uio.no (+47 23074223)

13 Running Title: Alternative splicing identification by mass spectrometry 


\section{ABBREVIATIONS}

15 ASE - Alternative splicing events

16 TIS - Translational initiation site

17 FDR - False discovery rate

18 GTI-Seq - Global translational initiation sequencing

\section{INTRODUCTION}

20 The development of large-scale technologies, including genomics, has revolutionized life 
21 sciences. For example, the sequencing of the human genome in 2001 was a milestone in the

22 characterization of our genetic framework (Lander et al. 2001; Venter et al. 2001). The

23 advancement of sequencing technologies in the last few years has allowed the genome

24 sequencing of more than a thousand human individuals (1000 Genomes Project) (Consortium

25 2012). Likewise, the characterization of the transcriptome was also facilitated by these new

26 sequencing technologies. RNA-Seq techniques have allowed the identification of transcripts with

27 low copy numbers. Thus, the complete characterization of the transcriptome of different cell

28 types is already a reality today (Au et al. 2013; Peng et al. 2012; Xue et al. 2014). We know for

29 example about the large variability found in the transcriptomes of eukaryotes due to alternative

30 splicing and alternative polyadenylation. As a consequence of the emergence of these

31 technologies, an explosion of this type of data in public databanks and data repositories is already

32 occurring and exponential growth is expected for the next years. Improving bioinformatics

33 capabilities is crucial for the processing, storage and interpretation of results from large-scale

34 technologies.

35 While the technologies for sequencing of nucleic acids developed at an impressive speed,

36 the same did not happen with technologies for sequencing amino acids and proteins. Recently,

37 mass spectrometry-based proteomics achieved enough comprehensiveness and throughput to

38 allow in-depth characterization of "complete proteomes" (Beck et al. 2011; Nagaraj et al. 2011).

39 However, proteomic data acquisition is still restricted to few groups, even though public

40 availability of high depth proteomic data is increasing (Desiere et al. 2006; Perez-Riverol et al.

41 2014; Vizcaino et al. 2013; Vizcaino et al. 2014).

42 Alternative splicing is defined, basically, as a process in which identical pre-mRNA

43 molecules are processed in different ways in terms of usage of splice sites. It is a fundamental

44 process in all multi-cellular organisms being responsible for the creation of a large diversity of

45 proteins from a relatively small number of genes (Cork et al. 2012). Alternative splicing events 
46 (ASE) have been extensively characterized using transcriptome data. On the other hand, only

47 recently proteome data have been used for global discovery of ASEs (Brosch et al. 2011;

48 Severing et al. 2011; Tress et al. 2008). This can be explained by two factors: first, limitations in

49 data acquisition, such as the lower dynamic range of rarer isoforms and consequently its

50 difficulty in collecting good quality fragmentation spectrum, resulting in poorer scoring and

51 higher chances for false-discovery reporting; second, protein identification by mass spectrometry

52 is still routinely performed through the use of protein databases cataloged and curated by public

53 repositories such as nrNCBI and Uniprot. Most of these databanks contain only a limited number

54 of protein sequence isoforms, and single nucleotide polymorphisms and ASEs are normally

55 under-represented. This is generally so because peptide identification approaches in proteomics

56 mostly use probabilistic-based algorithms, and excessively large databases would result in

57 spurious spectral matches and, therefore, reduced number of positive identifications (Perez-

58 Riverol et al. 2011; Wang et al. 2012; Woo et al. 2014). Thus, new approaches should be

59 developed where ASEs can be investigated without compromising database size and protein

60 identification rates. Several researchers have created strategies that use MS data repositories such

61 as Peptide Atlas and in silico protein database design using nucleotide sequence repositories or

62 merging protein sequence databases (Blakeley et al. 2010; Brosch et al. 2011). However, very

63 few had applied RNA-Seq data to offer isoform information at the transcriptome level, which

64 then could be validated at the protein level. For example, Sheynkman and colleagues

65 (Sheynkman et al. 2013) developed a strategy where RNA-Seq and MS data collected from the

66 same samples had been applied for the identification of splice junction peptides. However,

67 applying such different expertise in any project might not be a reality for a majority of

68 laboratories. Therefore, creating strategies that rely on heavy bioinformatics analysis of

69 nucleotide de novo sequence and validation through MS is relevant. 
71 FASTA database, built from repositories of expressed sequences, which was then challenged by

72 MS data. Our group had recently developed Splooce, a database that integrates information from

73 transcriptome analysis, including RNA-Seq, to identify splicing variants (Kroll et al. 2012).

74 Protein entries created from Splooce were evaluated using MS/MS analysis, and a large number

75 of novel proteins isoforms were identified. Surprisingly we found that around $40 \%$ of all

76 modifications at the protein level were related to the use of alternative translation initiation sites

77 (TIS).

\section{MATERIALS \& METHODS}

\section{Protein variants identification using mass spectrometry and MaxQuant}

Predicted proteins were collected from the Splooce website. Since Splooce does not provide FASTA files and due to the complexity of our needs (large scale analysis), a robot-type script was developed to query alternative splicing events and their specific data, such as predicted proteins. Entries showing alternative splicing events supported only by ESTs and/or RNASeq expressed sequences were selected. Those events were tagged as rare since they were not found in the set of full-insert cDNA sequences (RefSeq, mRNA), which usually have well characterized coding sequences. Any pattern of combined alternative splicing event was allowed. As default parameter, Splooce only reports events that are supported by at least two expressed sequences. For the prediction of protein sequences, Splooce uses a simple ab-initio strategy. Briefly, human entries from the Reference Sequence database (Pruitt et al. 2014) were modified by introducing alternative splicing patterns observed from the transcriptome data. Thus, full-length alternative cDNA sequences were created from expressed sequence fragments that often cover only a small fraction of coding sequences. As a final step, prior to the translation process, new open reading frames are predicted based on their length (largest one). Only alternative predicted proteins showing alterations on their amino acids composition were selected and, prior to be stored in the 
95 FASTA file, the sequences were tagged following the rule:

96 REFSEQ_NAME\#(EVENT_TYPE:SPLOOCE_ID). Our final set of predicted proteins,

97 containing 120,299 entries, can be downloaded from http://www.bioinformatics-

98 brazil.org/ jkroll/sploocemm. Additionally, we developed a simple tracking tool, available in

99 http://www.bioinformatics-brazil.org/cgi-jkroll/msretry.pl, which users can use to easily recover

100 information from any entry stored in the provided FASTA file. Human entries from Uniprot

101 (Reference Proteome, including 89,628 canonical and isoform entries, downloaded 16 ${ }^{\text {th }}$ Dec 2013

102 from http://www.uniprot.org) (Magrane \& Consortium 2011) were added to the Splooce database

103 to facilitate the visualization of identified peptides that are not unique to the Splooce set. Original

104 identifiers from Uniprot were maintained throughout all further analyses. The final database

105 contained 209,927 entries (89,628 and 120,299 from Uniprot and Splooce, respectively).

106 We submitted the collection of entries from Splooce plus Uniprot to a dataset of MS/MS

107 peptide information collected from 11 tumor cell lines that were publicly available at the Tranche

108 Network (currently discontinued (Perez-Riverol et al. 2014)). The whole collection of MS data

109 was derived from the laboratory of Dr. Mathias Mann (Geiger et al. 2012). Four RAW files from

110 this dataset were not used because they were apparently corrupted in the depository. We

111 submitted the remaining files to a MaxQuant (version 1.4.1.2) (Cox \& Mann 2008) search using

112 the following parameters: trypsin with no proline restriction as enzyme, initial search with a

113 precursor mass tolerance of $20 \mathrm{ppm}$ that were used for mass recalibration; main search precursor

114 mass and fragment mass were searched with mass tolerance of $6 \mathrm{ppm}$. The search included

115 variable modifications such as Met oxidation, N-terminal acetylation (protein), and Pyro-Glu (Q)

116 (E). Carbamidomethyl cysteine was added as a fixed modification. Minimal peptide length was

117 set to 7 amino acids and a maximum of two miscleavages were allowed. The false discovery rate

118 (FDR) was set to 0.01 for peptide and protein identifications. In the case of identified peptides

119 that are shared between two proteins, these are combined and reported as one protein group. 
120 Protein table output was filtered to eliminate the identifications from the reverse database, and

121 common contaminants.

122

123

124

125

126

127

128

129

130

131

132

133

134

135

136

137

138

139

140

141

142

143

3

\section{Protein variants identification using a de novo strategy}

We also decided to test the ability to identify peptides characterizing ASEs using a de novo approach rather than a probabilistic one using a database. MS raw files were submitted to de novo sequence identification using the PEAKS software (Ma et al. 2003). Parameters were set as: i) trypsin with no proline restriction as enzyme, ii) two miscleavages allowed and iii) precursor ion and fragment ion error of $10 \mathrm{ppm}$. Furthermore, carbamidomethyl (Cys) as fixed modification, while protein N-term acetylation, Met oxidation and pyro-Glu (Q / E) were also allowed as variable modifications. Only peptide sequences with more than $80 \%$ average coverage certainty were selected for further analysis. Coverage certainty is calculated on an amino acid per amino acid basis, i.e., only in cases where the software was able to precisely detect mass of the amino acid removed from two neighboring daughter ions.

\section{Identification of peptides supporting alternative splicing events}

The output file of identified peptides obtained from MaxQuant and PEAKS were filtered for peptides observed uniquely on Splooce entries. As described above, all MaxQuant peptides showing reversed and contaminant tags were removed from the data set. The resulting peptides were then compared against an unmodified set of RefSeq sequences, which Splooce uses as template for predicting new proteins. Any peptide observed for a Splooce entry, but not observed for its respective unmodified RefSeq, was classified as an ASE supporting peptide since it aligns uniquely to the alternative protein sequence. Additionally, any ASE supporting peptides matching the beginning of proteins were classified as alternative translation start sites.

A clear limitation in a "database-based" approach is a reduction in peptide/protein 


\section{PeerJ Reviewing Manuscript}

144 identification due to an increase in the search space by creating an excessively large database.

145 Therefore we restricted our database to a size approximately twice as big as Uniprot. Protein

146 identification using our database obtained approximately 500 proteins less than the original

147 publication, a variation of less than $5 \%$. Since the original publication used a version of the

148 discontinued International Protein Index database, we also submitted the dataset to Uniprot

149 database without our in house Splooce sequences (data not shown), since Uniprot and IPI would

150 have closer number of entries and therefore, similar search space (Griss et al. 2011). The Uniprot

151 result identified approximately 200 proteins less than the original publication. Such differences

152 are probably due to: i) different identified unique entries in Uniprot or IPI, ii) small differences in

153 the parameters between our MaxQuant search and the original publication, and/or iii) differences

154 in MaxQuant performance since we used an updated version compared to the one used the

155 original publication. Regardless, we concluded that even doubling the database size with Splooce

156 entries, protein identification penalty was irrelevant for the approach efficiency.

\section{RESULTS AND DISCUSSION}

\section{Identification of splicing variants in the MS/MS data}

Splooce was used as a source to create a database of predicted protein isoforms in FASTA

160 format, which was then searched against MS/MS spectra. A data set of 120,299 non-redundant

161 protein sequences was created based on rare ASEs that were not observed for full-insert cDNA

162 sequences (see Experimental Procedures for more details). That data set was merged to 89,602

163 Uniprot entries from the December 2013 release. A public collection of MS RAW files was then

164 selected for protein identification. Only files from a publication that reported good level of

165 instrument sensitivity and proteomic depth (Geiger et al. 2012) were used and the MS dataset was

166 challenged against the Splooce-derived protein sequences using two peptide identification

167 approaches, one based in probabilistic method and another one based on de novo sequencing 


\section{PeerJ Reviewing Manuscript}

168 (Figure 1). Both methods offer unique advantages and limitations. De novo sequencing provides

169 unbiased peptide identification, not limited to its theoretical existence in a database. On the other

170 hand, sequence information can only be obtained from good to high quality MS/MS data, and

171 partial sequence information is generally discarded. Algorithms using a protein database overall

172 offer a higher identification rate, since partial sequence information, together with accurate mass

173 measurement of the precursor peptide ion, can still provide positive identification. De novo data

174 also offer additional possibilities since once a given sequence information is obtained it can be

175 aligned against sequence repositories to provide protein identification.

176 Initial analysis using the probabilistic approach (MaxQuant) allowed us to identify a total

177 of 142,926 unique peptides representing 11,237 protein groups. Supplementary files S1 reports

178 the MaxQuant peptide output containing the identification features for both the total peptides

179 identified and the ones identified only in the Splooce database. As expected, the vast majority

$180(142,008)$ of these peptides are already present in Uniprot. However, 911 peptides, representing

181808 ASE, were only observed for Splooce entries.

182 We next plotted individual peptide intensities and scores from both the complete peptide

183 dataset and peptides uniquely identified in Splooce. Data overview of the complete dataset

184 showed, as previously reported, an intensity span of 7 orders of magnitude. The peptides

185 characterizing the rare ASEs were observed mostly at the bottom half of the intensity

186 distributions, with an average distribution approximately one order of magnitude lower than the

187 complete Uniprot set (Figure 2A). While the score distribution seemed similar, ASE-derived

188 peptides, on average, had a lower distribution (Figure 2B), which could be a consequence of

189 poorer MS/MS from lower intensity ions.

190 In addition, the same RAW files collection was submitted to PEAKS, a software capable

191 of determining a MS/MS sequence without the support of a database. Since no FDR can be

192 estimated without the support of reversed sequences artificially created from a database, this 
193 analysis was restricted to spectra where fragment ion mass sequences could be measure with an

194 average confidence of at least $80 \%$. Using this approach, approximately 50,000 peptides were

195 identified in Uniprot and Splooce (data not shown), and from those only 236 peptides, confirming

196218 splicing events, could be identified in the same Splooce-derived database as used in the

197 probabilistic approach. From those, 134 ASE were already observed in the probabilistic

198 approach. By merging the results of the two strategies, we characterized a total of 892 ASE

199 (Supplementary File S2 and S3). However, it is important to note that, while both de novo and

200 probabilistic methods have their own FDR calculations, we did not perform any additional

201 validation to avoid error propagation from merging results from the two different approaches.

202 Our objective here was mostly to investigate the most efficient method based on the reported

203 findings.

204 As expected, the de novo method identified a smaller proportion of proteins and peptides

205 than the probabilistic method when submitted to a BLAST-like alignment versus the same

206 Splooce database. In fact, a smaller number of splicing events were detected in the de novo

207 method when compared to the probabilistic one. An explanation for this could be that since most

208 ASE events characterized by the probabilistic method are seen in the bottom part of signal

209 intensity, they most probably generated partial MS/MS information that did not fulfilled the

210 criteria required by us for reporting good quality de novo sequences. With this observation we

211 therefore conclude that performing a probabilistic method using an in house database generates

212 more information than de novo sequencing.

213 The frequency of each type of alternative splicing was next calculated for all events

214 identified in our strategy. Simple events like exon skipping, alternative splice borders and intron

215 retention corresponded to 463 of the total number of events identified by MS/MS data and

216 showed proportional frequencies when compared to general Splooce statistics (Table 1).

217 Moreover, no ASEs resulting from dual-specificity splice sites were identified, since these events 
218 are very uncommon and usually found within UTR sequences (Zhang et al. 2007). Splooce is also

219 a database that focus on the analysis of combined ASEs (CASEs), and it was previously shown

220 that approximately half of all alternative expressed sequences may have more than one ASE

221 along their sequences (Kroll et al. 2012). The analysis presented here confirms the same finding

222 at the proteome level. Among the total amount of events identified by MS/MS data, 429 were

223 classified as complex. The most frequent combined event was the skipping of several adjacent

224 exons (up to 11 exons), followed by adjacent alternative splice sites.

225 Alternative TIS represents the majority of events at the proteome level

226 We further explored what types of events were observed in the identified peptides.

227 Interestingly, 355 ASEs, out of the $892(40 \%)$, showed a pattern consistent with the use of an

228 alternative TIS due to an ASE (Figure3, Supplementary File S2). The remaining 537 proteins

229 showed different types of variations along their protein sequences (Supplementary file S3). Files

230 S2 and S3 not only contain a resumed version of the results described in this section, but also

231 report protein sequence alignments for Uniprot and Splooce sequences of all proteins identified

232 with a rare ASE. Peptides shared between both databases, in addition to the Splooce-specific

233 peptide(s), are highlighted in the alignment. Most importantly, each alignment contains a link to

234 the Splooce website where information and statistics for that rare ASE can be collected.

235 The high proportion of alternative TIS was further explored. All new protein isoforms

236 showing an alternative TIS were searched against the TISdb database (Wan \& Qian 2014), a

237 collection of TIS obtained from a genome-wide method (GTI-Seq) developed by the same

238 authors (Lee et al. 2012). We found that only one TIS present in our list was present in the TISdb

239 providing therefore a proteome validation for that respective TISdb entry. Several reasons could

240 explain the small overlap between the two datasets such as: i) the different nature of the samples

241 used in both studies, ii) the fact that most of the TIS present in TISdb are non-canonical and start

242 with others codons than ATG (we restricted our analysis to ATG-associated TIS) and iii) the lack 


\section{PeerJ Reviewing Manuscript}

243 of proteome validation in most of the studies that populated TISdb.

244 Wilson and colleagues have suggested that the association between ASE and TIS are

245 restricted to the amino-terminus of proteins where both events are used to produce isoforms that

246 differ at their amino end. Almost 2,000 events like that were identified at the transcriptome level

247 but few (17 instances) were confirmed in a limited search against MS/MS data (Wilson et al.

248 2014). We wondered whether this type of event would be frequent in our dataset of 355 TIS.

249 Visual inspection of all 355 cases identified only 29 instances (8\%) that would fit the model from

250 Wilson et al., (2014) (for more details, see Supplementary file S2). The low level of validation of

251 such cases at the proteome level, also seen by the authors in their original report, raises doubts

252 about their widespread occurrence. All remaining 326 cases of TIS in our dataset were analyzed

253 to identify the effect of the ASE in the protein sequence originally present in the reference

254 sequence. In only three cases, the alternative TIS was upstream of the original ATG codon. In all

255 remaining cases, the ASE occurred upstream of the alternative TIS and disrupted the respective

256 ORF. An alternative ATG codon, always located downstream of the ASE, is then used as a new

257 TIS. Interestingly, only in $15 \%$ of these cases (48 out of 323) the ATG codon used in the TIS is

258 the first one downstream of the ASE.

\section{CONCLUSIONS}

260 A limitation one is facing in this type of analysis the definition of a proper false discovery

261 rate when adding entries in a database ad infinitum. Any observed MS/MS information in such

262 approaches will be tagged to the "best-fit" theoretical peptide present in the database, regardless

263 if that is the correct one. Even though identification engines such as Mascot and MaxQuant

264 (Andromeda) have proof-check algorithms to quantify FDR rate, incorrect MS/MS information

265 might still be reported as true. Therefore there will be always the risk that peptides that are

266 present in the sample but not represented in the database are incorrectly assigned. In addition, 
267 there will be a size limit where adding more protein entries created by RNAseq information will

268 be detrimental to the analysis, rather than beneficial. For a good isoform discovery phase study to

269 reliably work, a compromise between database size and validation rounds using complementary

270 databases must be created. A desirable strategy would be to create a collection of public, high

271 quality datasets such as the one used in this work and use them for database-based splicing

272 discovery using different versions of the Splooce database. Recently, similar approaches have

273 been successfully implemented for mapping expressed genes, pseudogenes and characterization

274 of new open reading frames (Kim et al. 2014; Wilhelm et al. 2014), but little was shown

275 regarding splicing isoforms. Therefore, such approach using Splooce databases with public MS

276 data for ASE discovery is feasible and promising for further characterization of the human

277 proteome draft. Our data demonstrate that by simply complementing routinely used databases

278 with rare/unknown isoform entries predicted by nucleotide sequences approaches, together with

279 already in-use protein identification engines such as MaxQuant/Andromeda can provide

280 satisfactory identification rates without compromising the search engine capabilities.

281 In summary, a new strategy for the identification of splicing variants in MS/MS data is

282 provided here allowing us to confirm at the proteome level more than 800 new variants. We

283 extended previous observations linking ASE and TIS and provided validation for hundreds of

284 new TIS events. We have upgraded the Splooce portal to take into account the integration of

285 MS/MS data in the validation of splicing variants. 
286

287

288

289

290

291

292

293

294

295

296

297

298

299

300

301

302

303

304

305

306

307

308

309

310

311

312

313

314

315

316

317

318

319

320

321

322

323

324

325

326

327

328

329

330

331

332

333

334

\section{References}

Au KF, Sebastiano V, Afshar PT, Durruthy JD, Lee L, Williams BA, van Bakel H, Schadt EE, Reijo-Pera RA, Underwood JG, and Wong WH. 2013. Characterization of the human ESC transcriptome by hybrid sequencing. Proc Natl Acad Sci U S A 110:E4821-E4830.

Beck M, Schmidt A, Malmstroem J, Claassen M, Ori A, Szymborska A, Herzog F, Rinner O, Ellenberg J, and Aebersold R. 2011. The quantitative proteome of a human cell line. Molecular systems biology 7:549.

Blakeley P, Siepen JA, Lawless C, and Hubbard SJ. 2010. Investigating protein isoforms via proteomics: a feasibility study. Proteomics 10:1127-1140.

Brosch M, Saunders GI, Frankish A, Collins MO, Yu L, Wright J, Verstraten R, Adams DJ, Harrow J, Choudhary JS, and Hubbard T. 2011. Shotgun proteomics aids discovery of novel protein-coding genes, alternative splicing, and "resurrected" pseudogenes in the mouse genome. Genome Res 21:756-767.

Consortium TGP. 2012. An integrated map of genetic variation from 1,092 human genomes. Nature 491:56-65.

Cork DMW, Lennard TWJ, and Tyson-Capper AJ. 2012. Progesterone receptor (PR) variants exist in breast cancer cells characterised as PR negative. Tumour Biol 33:2329-2340.

Cox J, and Mann M. 2008. MaxQuant enables high peptide identification rates, individualized p.p.b.-range mass accuracies and proteome-wide protein quantification. Nature biotechnology 26:1367-1372.

Desiere F, Deutsch EW, King NL, Nesvizhskii AI, Mallick P, Eng J, Chen S, Eddes J, Loevenich SN, and Aebersold R. 2006. The PeptideAtlas project. Nucleic Acids Res 34:D655-658.

Geiger T, Wehner A, Schaab C, Cox J, and Mann M. 2012. Comparative proteomic analysis of eleven common cell lines reveals ubiquitous but varying expression of most proteins. Mol Cell Proteomics 11:M111 014050.

Griss J, Martin M, O'Donovan C, Apweiler R, Hermjakob H, and Vizcaino JA. 2011. Consequences of the discontinuation of the International Protein Index (IPI) database and its substitution by the UniProtKB "complete proteome" sets. Proteomics 11:4434-4438.

Kim MS, Pinto SM, Getnet D, Nirujogi RS, Manda SS, Chaerkady R, Madugundu AK, Kelkar DS, Isserlin R, Jain S, Thomas JK, Muthusamy B, Leal-Rojas P, Kumar P, Sahasrabuddhe NA, Balakrishnan L, Advani J, George B, Renuse S, Selvan LD, Patil AH, Nanjappa V, Radhakrishnan A, Prasad S, Subbannayya T, Raju R, Kumar M, Sreenivasamurthy SK, Marimuthu A, Sathe GJ, Chavan S, Datta KK, Subbannayya Y, Sahu A, Yelamanchi SD, Jayaram S, Rajagopalan P, Sharma J, Murthy KR, Syed N, Goel R, Khan AA, Ahmad S, Dey G, Mudgal K, Chatterjee A, Huang TC, Zhong J, Wu X, Shaw PG, Freed D, Zahari MS, Mukherjee KK, Shankar S, Mahadevan A, Lam H, Mitchell CJ, Shankar SK, Satishchandra P, Schroeder JT, Sirdeshmukh R, Maitra A, Leach SD, Drake CG, Halushka MK, Prasad TS, Hruban RH, Kerr CL, Bader GD, Iacobuzio-Donahue CA, Gowda H, and Pandey A. 2014. A draft map of the human proteome. Nature 509:575-581.

Kroll JE, Galante PA, Ohara DT, Navarro FC, Ohno-Machado L, and de Souza SJ. 2012. SPLOOCE: a new portal for the analysis of human splicing variants. RNA Biol 9:13391343.

Lander ES, Linton LM, Birren B, Nusbaum C, Zody MC, Baldwin J, Devon K, Dewar K, Doyle M, FitzHugh W, Funke R, Gage D, Harris K, Heaford A, Howland J, Kann L, Lehoczky J, LeVine R, McEwan P, McKernan K, Meldrim J, Mesirov JP, Miranda C, Morris W, Naylor J, Raymond C, Rosetti M, Santos R, Sheridan A, Sougnez C, Stange-Thomann N, Stojanovic N, Subramanian A, Wyman D, Rogers J, Sulston J, Ainscough R, Beck S, Bentley D, Burton J, Clee C, Carter N, Coulson A, Deadman R, Deloukas P, Dunham A, Dunham I, Durbin R, French L, Grafham D, Gregory S, Hubbard T, Humphray S, Hunt A, 

A, Plumb R, Ross M, Shownkeen R, Sims S, Waterston RH, Wilson RK, Hillier LW, McPherson JD, Marra MA, Mardis ER, Fulton LA, Chinwalla AT, Pepin KH, Gish WR, Chissoe SL, Wendl MC, Delehaunty KD, Miner TL, Delehaunty A, Kramer JB, Cook LL, Fulton RS, Johnson DL, Minx PJ, Clifton SW, Hawkins T, Branscomb E, Predki P, Richardson P, Wenning S, Slezak T, Doggett N, Cheng JF, Olsen A, Lucas S, Elkin C, Uberbacher E, Frazier M, Gibbs RA, Muzny DM, Scherer SE, Bouck JB, Sodergren EJ, Worley KC, Rives CM, Gorrell JH, Metzker ML, Naylor SL, Kucherlapati RS, Nelson DL, Weinstock GM, Sakaki Y, Fujiyama A, Hattori M, Yada T, Toyoda A, Itoh T, Kawagoe C, Watanabe H, Totoki Y, Taylor T, Weissenbach J, Heilig R, Saurin W, Artiguenave F, Brottier P, Bruls T, Pelletier E, Robert C, Wincker P, Smith DR, DoucetteStamm L, Rubenfield M, Weinstock K, Lee HM, Dubois J, Rosenthal A, Platzer M, Nyakatura G, Taudien S, Rump A, Yang H, Yu J, Wang J, Huang G, Gu J, Hood L, Rowen L, Madan A, Qin S, Davis RW, Federspiel NA, Abola AP, Proctor MJ, Myers RM, Schmutz J, Dickson M, Grimwood J, Cox DR, Olson MV, Kaul R, Raymond C, Shimizu N, Kawasaki K, Minoshima S, Evans GA, Athanasiou M, Schultz R, Roe BA, Chen F, Pan H, Ramser J, Lehrach H, Reinhardt R, McCombie WR, de la Bastide M, Dedhia N, Blocker H, Hornischer K, Nordsiek G, Agarwala R, Aravind L, Bailey JA, Bateman A, Batzoglou S, Birney E, Bork P, Brown DG, Burge CB, Cerutti L, Chen HC, Church D, Clamp M, Copley RR, Doerks T, Eddy SR, Eichler EE, Furey TS, Galagan J, Gilbert JG, Harmon C, Hayashizaki Y, Haussler D, Hermjakob H, Hokamp K, Jang W, Johnson LS, Jones TA, Kasif S, Kaspryzk A, Kennedy S, Kent WJ, Kitts P, Koonin EV, Korf I, Kulp D, Lancet D, Lowe TM, McLysaght A, Mikkelsen T, Moran JV, Mulder N, Pollara VJ, Ponting CP, Schuler G, Schultz J, Slater G, Smit AF, Stupka E, Szustakowski J, ThierryMieg D, Thierry-Mieg J, Wagner L, Wallis J, Wheeler R, Williams A, Wolf YI, Wolfe KH, Yang SP, Yeh RF, Collins F, Guyer MS, Peterson J, Felsenfeld A, Wetterstrand KA, Patrinos A, Morgan MJ, de Jong P, Catanese JJ, Osoegawa K, Shizuya H, Choi S, Chen YJ, and International Human Genome Sequencing C. 2001. Initial sequencing and analysis of the human genome. Nature 409:860-921.

Lee S, Liu B, Lee S, Huang SX, Shen B, and Qian SB. 2012. Global mapping of translation initiation sites in mammalian cells at single-nucleotide resolution. Proc Natl Acad Sci U S A 109:E2424-2432.

Ma B, Zhang K, Hendrie C, Liang C, Li M, Doherty-Kirby A, and Lajoie G. 2003. PEAKS: powerful software for peptide de novo sequencing by tandem mass spectrometry. Rapid Commun Mass Spectrom 17:2337-2342.

Magrane M, and Consortium U. 2011. UniProt Knowledgebase: a hub of integrated protein data. Database (Oxford) 2011:bar009.

Nagaraj N, Wisniewski JR, Geiger T, Cox J, Kircher M, Kelso J, Paabo S, and Mann M. 2011. Deep proteome and transcriptome mapping of a human cancer cell line. Molecular systems biology 7:548.

Peng Z, Cheng Y, Tan BC-M, Kang L, Tian Z, Zhu Y, Zhang W, Liang Y, Hu X, Tan X, and et al. 2012. Comprehensive analysis of RNA-Seq data reveals extensive RNA editing in a human transcriptome. Nature biotechnology 30:253-260.

Perez-Riverol Y, Alpi E, Wang R, Hermjakob H, and Vizcaino JA. 2014. Making proteomics data accessible and reusable: Current state of proteomics databases and repositories. Proteomics.

Perez-Riverol Y, Sanchez A, Ramos Y, Schmidt A, Muller M, Betancourt L, Gonzalez LJ, Vera R, Padron G, and Besada V. 2011. In silico analysis of accurate proteomics, complemented by selective isolation of peptides. J Proteomics 74:2071-2082. 
384

385

386

387

388

389

390

391

392

393

394

395

396

397

398

399

400

401

402

403

404

405

406

407

408

409

410

411

412

413

414

415

416

417

418

419

420

421

422

423

424

425

426

427

428

429

430

431

432

Pruitt KD, Brown GR, Hiatt SM, Thibaud-Nissen Fc, ,oise, Astashyn A, Ermolaeva O, Farrell CM, Hart J, Landrum MJ, McGarvey KM, Murphy MR, O'Leary NA, Pujar S, Rajput B, Rangwala SH, Riddick LD, Shkeda A, Sun H, Tamez P, Tully RE, Wallin C, Webb D, Weber J, Wu W, DiCuccio M, Kitts P, Maglott DR, Murphy TD, and Ostell JM. 2014. RefSeq: an update on mammalian reference sequences. Nucleic Acids Res 42:D756-D763. Severing EI, van Dijk AD, and van Ham RC. 2011. Assessing the contribution of alternative splicing to proteome diversity in Arabidopsis thaliana using proteomics data. BMC Plant Biol 11:82.

Sheynkman GM, Shortreed MR, Frey BL, and Smith LM. 2013. Discovery and mass spectrometric analysis of novel splice-junction peptides using RNA-Seq. Mol Cell Proteomics 12:2341-2353.

Tress ML, Bodenmiller B, Aebersold R, and Valencia A. 2008. Proteomics studies confirm the presence of alternative protein isoforms on a large scale. Genome Biol 9:R162.

Venter JC, Adams MD, Myers EW, Li PW, Mural RJ, Sutton GG, Smith HO, Yandell M, Evans CA, Holt RA, Gocayne JD, Amanatides P, Ballew RM, Huson DH, Wortman JR, Zhang Q, Kodira CD, Zheng XH, Chen L, Skupski M, Subramanian G, Thomas PD, Zhang J, Gabor Miklos GL, Nelson C, Broder S, Clark AG, Nadeau J, McKusick VA, Zinder N, Levine AJ, Roberts RJ, Simon M, Slayman C, Hunkapiller M, Bolanos R, Delcher A, Dew I, Fasulo D, Flanigan M, Florea L, Halpern A, Hannenhalli S, Kravitz S, Levy S, Mobarry C, Reinert K, Remington K, Abu-Threideh J, Beasley E, Biddick K, Bonazzi V, Brandon R, Cargill M, Chandramouliswaran I, Charlab R, Chaturvedi K, Deng Z, Di Francesco V, Dunn P, Eilbeck K, Evangelista C, Gabrielian AE, Gan W, Ge W, Gong F, Gu Z, Guan P, Heiman TJ, Higgins ME, Ji RR, Ke Z, Ketchum KA, Lai Z, Lei Y, Li Z, Li J, Liang Y, Lin X, Lu F, Merkulov GV, Milshina N, Moore HM, Naik AK, Narayan VA, Neelam B, Nusskern D, Rusch DB, Salzberg S, Shao W, Shue B, Sun J, Wang Z, Wang A, Wang X, Wang J, Wei M, Wides R, Xiao C, Yan C, Yao A, Ye J, Zhan M, Zhang W, Zhang H, Zhao Q, Zheng L, Zhong F, Zhong W, Zhu S, Zhao S, Gilbert D, Baumhueter S, Spier G, Carter C, Cravchik A, Woodage T, Ali F, An H, Awe A, Baldwin D, Baden H, Barnstead M, Barrow I, Beeson K, Busam D, Carver A, Center A, Cheng ML, Curry L, Danaher S, Davenport L, Desilets R, Dietz S, Dodson K, Doup L, Ferriera S, Garg N, Gluecksmann A, Hart B, Haynes J, Haynes C, Heiner C, Hladun S, Hostin D, Houck J, Howland T, Ibegwam C, Johnson J, Kalush F, Kline L, Koduru S, Love A, Mann F, May D, McCawley S, McIntosh T, McMullen I, Moy M, Moy L, Murphy B, Nelson K, Pfannkoch C, Pratts E, Puri V, Qureshi H, Reardon M, Rodriguez R, Rogers YH, Romblad D, Ruhfel B, Scott R, Sitter C, Smallwood M, Stewart E, Strong R, Suh E, Thomas R, Tint NN, Tse S, Vech C, Wang G, Wetter J, Williams S, Williams M, Windsor S, Winn-Deen E, Wolfe K, Zaveri J, Zaveri K, Abril JF, Guigo R, Campbell MJ, Sjolander KV, Karlak B, Kejariwal A, Mi H, Lazareva B, Hatton T, Narechania A, Diemer K, Muruganujan A, Guo N, Sato S, Bafna V, Istrail S, Lippert R, Schwartz R, Walenz B, Yooseph S, Allen D, Basu A, Baxendale J, Blick L, Caminha M, Carnes-Stine J, Caulk P, Chiang YH, Coyne M, Dahlke C, Mays A, Dombroski M, Donnelly M, Ely D, Esparham S, Fosler C, Gire H, Glanowski S, Glasser K, Glodek A, Gorokhov M, Graham K, Gropman B, Harris M, Heil J, Henderson S, Hoover J, Jennings D, Jordan C, Jordan J, Kasha J, Kagan L, Kraft C, Levitsky A, Lewis M, Liu X, Lopez J, Ma D, Majoros W, McDaniel J, Murphy S, Newman M, Nguyen T, Nguyen N, Nodell M, Pan S, Peck J, Peterson M, Rowe W, Sanders R, Scott J, Simpson M, Smith T, Sprague A, Stockwell T, Turner R, Venter E, Wang M, Wen M, Wu D, Wu M, Xia A, Zandieh A, and Zhu X. 2001. The sequence of the human genome. Science 291:1304-1351.

Vizcaino JA, Cote RG, Csordas A, Dianes JA, Fabregat A, Foster JM, Griss J, Alpi E, Birim M, 
433

434

435

436

437

438

439

440

441

442

443

444

445

446

447

448

449

450

451

452

453

454

455

456

457

458

459

460

461

462

463
Contell J, O'Kelly G, Schoenegger A, Ovelleiro D, Perez-Riverol Y, Reisinger F, Rios D, Wang R, and Hermjakob H. 2013. The PRoteomics IDEntifications (PRIDE) database and associated tools: status in 2013. Nucleic Acids Res 41:D1063-1069.

Vizcaino JA, Deutsch EW, Wang R, Csordas A, Reisinger F, Rios D, Dianes JA, Sun Z, Farrah T, Bandeira N, Binz PA, Xenarios I, Eisenacher M, Mayer G, Gatto L, Campos A, Chalkley RJ, Kraus HJ, Albar JP, Martinez-Bartolome S, Apweiler R, Omenn GS, Martens L, Jones AR, and Hermjakob H. 2014. ProteomeXchange provides globally coordinated proteomics data submission and dissemination. Nature biotechnology 32:223-226.

Wan J, and Qian SB. 2014. TISdb: a database for alternative translation initiation in mammalian cells. Nucleic Acids Res 42:D845-850.

Wang X, Slebos RJ, Wang D, Halvey PJ, Tabb DL, Liebler DC, and Zhang B. 2012. Protein identification using customized protein sequence databases derived from RNA-Seq data. J Proteome Res 11:1009-1017.

Wilhelm M, Schlegl J, Hahne H, Moghaddas Gholami A, Lieberenz M, Savitski MM, Ziegler E, Butzmann L, Gessulat S, Marx H, Mathieson T, Lemeer S, Schnatbaum K, Reimer U, Wenschuh H, Mollenhauer M, Slotta-Huspenina J, Boese JH, Bantscheff M, Gerstmair A, Faerber F, and Kuster B. 2014. Mass-spectrometry-based draft of the human proteome. Nature 509:582-587.

Wilson LO, Spriggs A, Taylor JM, and Fahrer AM. 2014. A novel splicing outcome reveals more than 2000 new mammalian protein isoforms. Bioinformatics 30:151-156.

Woo S, Cha SW, Merrihew G, He Y, Castellana N, Guest C, MacCoss M, and Bafna V. 2014. Proteogenomic database construction driven from large scale RNA-seq data. $J$ Proteome Res 13:21-28.

Xue J, Schmidt SV, Sander J, Draffehn A, Krebs W, Quester I, De Nardo D, Gohel TD, Emde M, Schmidleithner L, Ganesan H, Nino-Castro A, Mallmann MR, Labzin L, Theis H, Kraut M, Beyer M, Latz E, Freeman TC, Ulas T, and Schultze JL. 2014. Transcriptome-based network analysis reveals a spectrum model of human macrophage activation. Immunity 40:274-288.

Zhang C, Hastings ML, Krainer AR, and Zhang MQ. 2007. Dual-specificity splice sites function alternatively as 5' and 3' splice sites. Proc Natl Acad Sci U S A 104:15028-15033. 
Figure 1

Experimental design flowchart.

Briefly, public MS data from 11 cell lines (Geiger et al., 2012) were submitted to peptide identification using a Splooce database either by a probabilistic approach (MaxQuant) or a de novo approach (PEAKS). Identified peptides were sorted and those characterizing alternative splicing events not present in Uniprot were compared. 


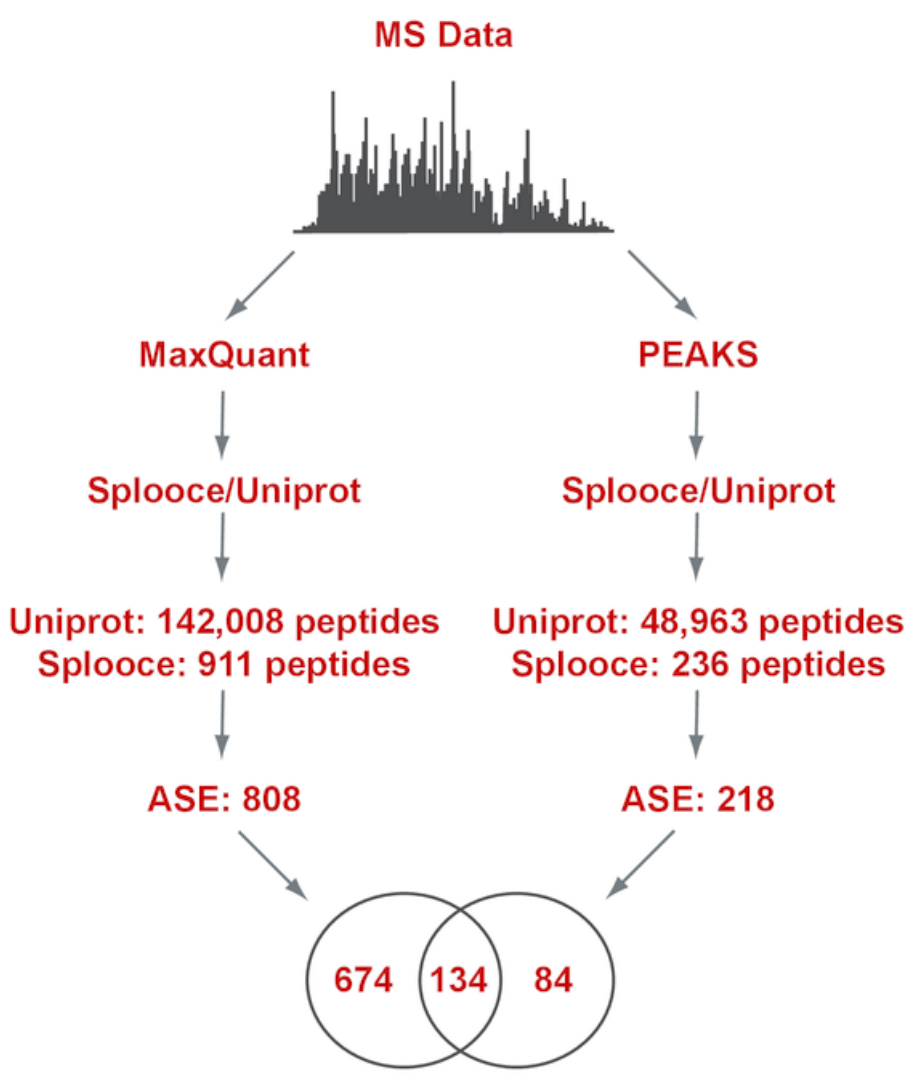


Figure 2

Intensity and scoring distribution for all identified peptides

Peptide signal intensity $(\log 10)(A)$ and scoring $(B)$ distribution for all peptides $(A L L)$ and sorted alternative splicing events (ASE) in the probabilistic approach. ASE peptides were on average close to an order of magnitude less abundant than the whole peptide population, consequently with lower average scoring.

A.

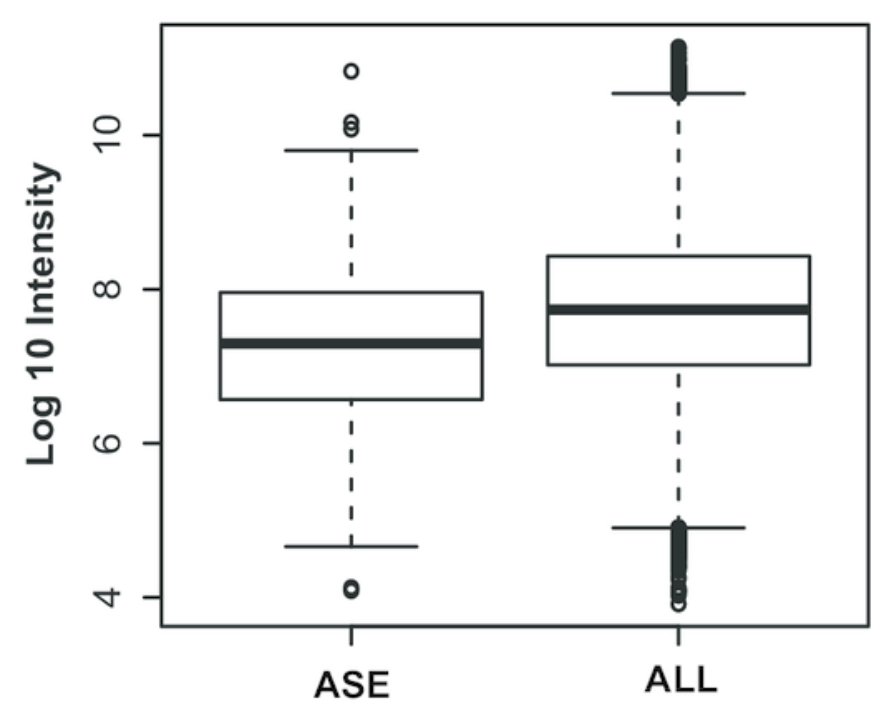

B.

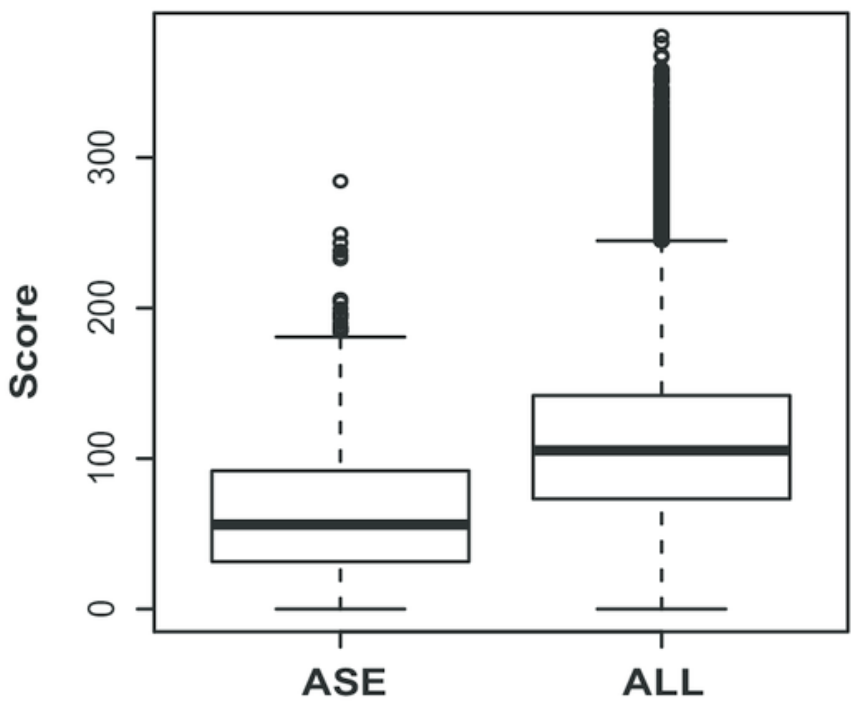




\section{Figure 3}

Alignments between normal (Uniprot/RefSeq) and alternative (Splooce) proteins, showing different categories of alternative TIS observed for our data.

Sequences highlighted in orange represent MS peptides found for the Uniprot/RefSeq proteins, and sequences highlighted in yellow represent peptides found exclusively in the alternative sequences from Splooce. Peptides that align specifically to a sequence from Splooce are supposed to characterize ASEs. A: Alternative TIS is downstream the original

one; B: Same as A, although the beginning of the protein sequence is directly affected by the ASE. C: Alternative TIS is upstream the original one. 


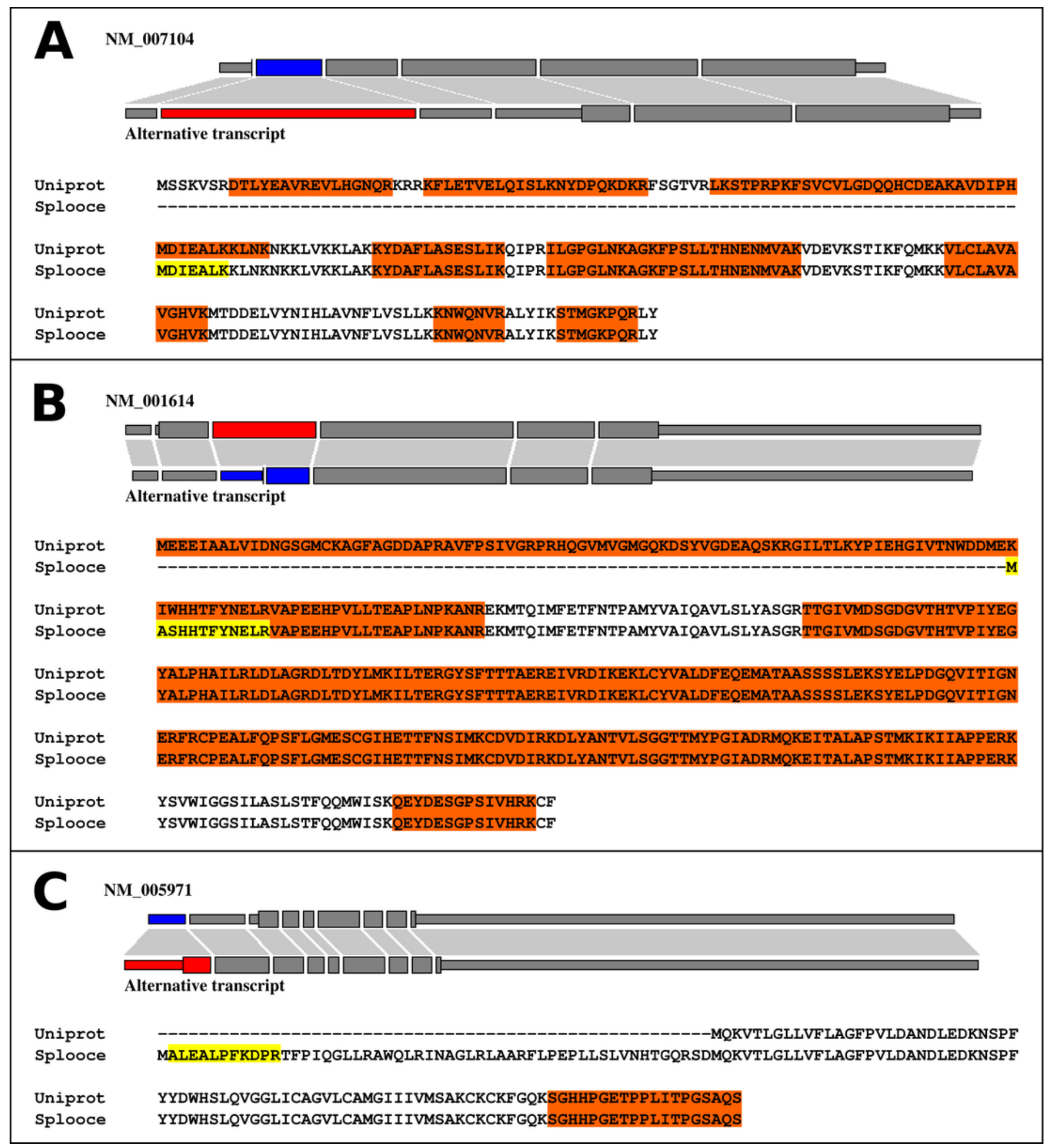




\section{Table $\mathbf{1}$ (on next page)}

Table 1. Amount of simple alternative splicing events identified by the MS/MS analysis compared to the total number of corresponding events available from the Splooce database. 


\begin{tabular}{|l|l|l|}
\hline Alternative Splicing Event & $\begin{array}{l}\text { Total Events from } \\
\text { Splooce }\end{array}$ & $\begin{array}{l}\text { Events identified by the MS/MS } \\
\text { analysis }\end{array}$ \\
\hline Exon skipping & $38060(35 \%)$ & $182(39 \%)$ \\
\hline Alternative 3' splice site & $30172(29 \%)$ & $130(28 \%)$ \\
\hline Alternative 5' splice site & $27585(25 \%)$ & $90(20 \%)$ \\
\hline Intron retention & $12632(11 \%)$ & $61(13 \%)$ \\
\hline Dual-specific splice site & $112(0 \%)$ & $0(0 \%)$ \\
\hline
\end{tabular}

